\title{
Short communication \\ Observations on daily rainfall events in the KwaZulu-Natal Drakensberg
}

\author{
W Nel* \\ Department of Geography and Environmental Science, University of Fort Hare, Alice 5700, South Africa
}

\begin{abstract}
Five-minute rainfall data measured at different stations in the KwaZulu-Natal Drakensberg are presented and although the data are limited this paper is the first to analyse individual rainfall events in the area. The occurrence of rain days in the Drakensberg shows strong seasonality with most rain recorded during the summer months. Although the number of rain days as well as the number of rainfall events increases with an increase in altitude, the mean daily rainfall and mean rainfall generated from individual events is less on the escarpment than in the foothills. All stations show a high percentage of rain days with single rainfall events as well as a high proportion of rainfall received from events generating more than $10 \mathrm{~mm}$, but the escarpment station receives less rainfall from these events than the stations in the foothills. It is known that rainfall in the Drakensberg is mostly generated from thunderstorms, and data presented here indicate that rainfall predominately occurs in the late afternoon/early evening when sufficient cooling has possibly taken place for condensation and cloud formation to occur.
\end{abstract}

Keywords: daily rainfall, rainfall events, rain days, Drakensberg

\section{Introduction}

Recently declared a Trans-Frontier National Park, the Drakensberg is part of the main escarpment of Southern Africa, which extends as a passive margin around the sub-continent and reaches above $3000 \mathrm{~m}$ on the watershed border between KwaZulu-Natal and Lesotho. There are two types of rain-producing systems in the Drakensberg (Tyson et al., 1976), i.e. large-scale line thunderstorms and orographically induced storms. These systems provide the major source of rainfall over the Drakensberg in the extended summer period, while frontal systems develop as closed low-pressure cells in the western Atlantic and move across Southern Africa in a west-northwest to east-southeast direction bringing widespread rainfall in winter (Tyson et al., 1976). Mean annual rainfall is estimated to vary between $700 \mathrm{~mm}$ in the northeast and south (Schulze, 1979) to over 1800 and $2000 \mathrm{~mm}$ on top of the escarpment (Tyson et al., 1975; Schulze, 1979). Recently, however, data collected by Nel and Sumner $(2005 ; 2008)$ from the southern and northern Drakensberg suggest that these earlier estimates of rainfall totals on the escarpment may be an over-estimation. Stations in the Drakensberg are known to experience an average of 16 to 18 rain days in the months of December and January (Tyson et al., 1976), and the summer months November to March account for $75 \%$ of the annual rainfall, whilst the period May to August accounts for less than 10\% (Nel and Sumner, 2006).

Given the remoteness of the area, especially the escarpment region, high-resolution rainfall data are sparse. Most of the above-mentioned rainfall analysis and estimations were done with daily or monthly rainfall totals, which is insufficient to assess the characteristics of individual rainfall events. This

* To whom all correspondence should be addressed.

용 +27 40 602-2146; fax: +27 43 738-5253;

e-mail: wnel@ufh.ac.za

Received 29 January 2007; accepted in revised form 17 March 2008. paper presents the first attempt to investigate the link between individual rainfall events and daily and total precipitation in the KwaZulu-Natal Drakensberg as part of ongoing meteorological monitoring in the high mountain regions of the South African eastern escarpment.

\section{Study sites and data collection}

Davis-MC Systems@ (D-MCS) automated tipping-bucket rain gauges were installed at five locations within the Drakensberg. The D-MCS rainfall gauges have a $163 \mathrm{~mm}$ collection diameter and $\log$ total rainfall every $5 \mathrm{~min}$ on a tipping resolution of 0.2 $\mathrm{mm}$. Records by the D-MCS are deemed comparable against manual recording rain-gauges used at the South African Weather Service stations (Nel and Sumner, 2005). Two sites on the escarpment edge are at the top of Sani Pass $\left(29.57^{\circ} \mathrm{S}, 29.27\right.$ E, 2850 $\mathrm{m}$ a.m.s.1.) in what is known as the southern Drakensberg and at the Sentinel Peak $\left(28.74^{\circ} \mathrm{S}, 28.89^{\circ} \mathrm{E}, 3165 \mathrm{~m}\right.$ a.m.s.l.) in the northern Drakensberg (Fig. 1). Rainfall gauges where also installed in the foothills at the Royal Natal National Park (RNNP) $\left(28.68^{\circ} \mathrm{S}, 28.95^{\circ} \mathrm{E}, 1392 \mathrm{~m}\right.$ a.m.s.l.) also in the north, and on the farm Glenisla $\left(29.02^{\circ} \mathrm{S}, 29.49^{\circ} \mathrm{E}, 1060 \mathrm{~m}\right.$ a.m.s.l.) and the Injisuthi Outpost $\left(29.13^{\circ} \mathrm{S}, 29.45^{\circ} \mathrm{E}, 1920 \mathrm{~m}\right.$ a.m.s.l.) both in the central Drakensberg (Fig. 1). All stations are on level ground with no favoured aspect. Five-minute rainfall data that have been analysed here were recorded over a 17-month ( $516 \mathrm{~d}$ ) period between December 2001 and April 2003 at all four stations (Sani Pass, Glenisla, Injisuthi Outpost and Royal Natal National Park) and during 2003 at the Sentinel Peak, Injisuthi Outpost and Royal Natal National Park. All rainfall gauges were operating correctly during these periods and no gaps in the data exist.

\section{Daily rainfall}

In this study daily rainfall is measured over a $24 \mathrm{~h}$ cycle from 00:00 to 00:00 the following day. Schulze (1979) defined a rain 


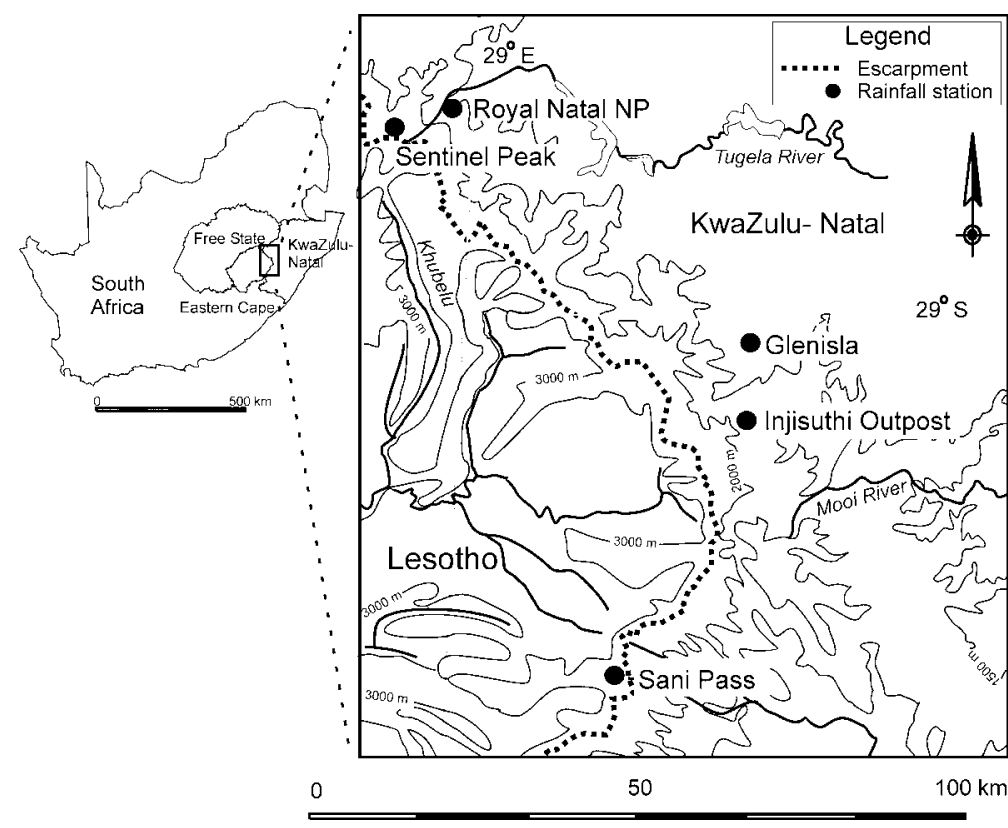

Figure 1

Map of the location of automated rainfall stations used in this study in the KwaZulu-Natal Drakensberg

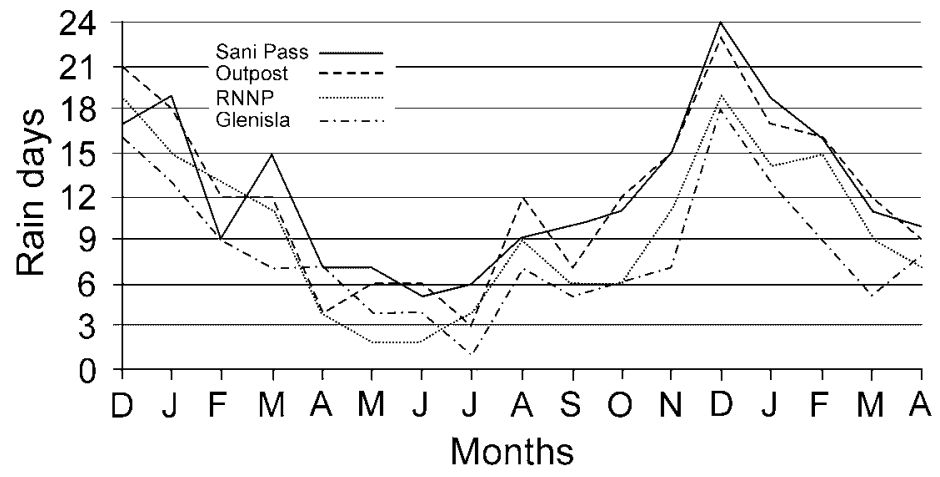

Figure 2

Number of monthly rain days recorded at the stations from December 2001 to April 2003

day in the Drakensberg as one on which at least $0.5 \mathrm{~mm}$ of rainfall is measured. For the purpose of a spatial study, and in order to allow for consistency with previous studies, this definition by Schulze (1979) of a rain day is also used here. Royal Natal National Park (RNNP) measured $1559.4 \mathrm{~mm}$ of rainfall from December 2001 to April 2003 in 166 rain days, while Sani
Pass, Injisuthi Outpost (Outpost) and Glenisla measured $1303.6 \mathrm{~mm}, 1345.6 \mathrm{~mm}$ and 1139.0 $\mathrm{mm}$ in 210, 205 and 139 rain days respectively (Table 1). Glenisla recorded the highest rainfall per day of $62.4 \mathrm{~mm}$, while RNNP, Sani Pass and the Outpost measured maximum daily rainfall of $59.8 \mathrm{~mm}, 55.6 \mathrm{~mm}$ and $44.4 \mathrm{~mm}$ respectively. Daily rainfall measured at RNNP shows that an average of $9.4 \mathrm{~mm}$ of rain is recorded per rain day. Glenisla, Outpost and Sani Pass measured lower rainfall per rain day of $8.2 \mathrm{~mm}, 6.7 \mathrm{~mm}$ and $6.2 \mathrm{~mm}$ respectively (Table 1). Differences can also be discerned when comparing rainfall totals and number of rain days measured during 2003 at RNNP (1 $392 \mathrm{~m}$ ) and Sentinel Peak (3 $165 \mathrm{~m})$ (Table 1). Even though these stations are in close proximity of each other, they have an altitude difference of $1773 \mathrm{~m}$. During 2003, Sentinel Peak recorded $754.4 \mathrm{~mm}$ of total daily rainfall that were measured in $115 \mathrm{~d}$. RNNP measured $773.0 \mathrm{~mm}$ but in only $96 \mathrm{~d}$, giving a mean of $8.1 \mathrm{~mm}$ of rainfall per rain day for 2003 (Table 1).

The monthly distribution of rain days measured at the different stations was calculated and all stations show that rain days predominate during the summer months (Fig. 2), with the highest number of rain days measured in December and the lowest in July. The high-altitude station, Sani Pass, has a higher number of rain days in total and also measured more rain days during the winter of 2002 (May to September) and the summer of 2002/03 than the stations at lower altitude (Fig. 2).

The amount of rainfall recorded in a certain hour as a percentage of total rainfall at the different stations was also considered (Fig. 3). Rainfall at all four stations predominantly falls in the latter part of the day with $75 \%$ of the total rainfall falling between 12:00 and 24:00. Most stations show peak rainfall in the late afternoon/early evening between 17:00 and $21: 00$ and $46 \%$ of the total rainfall was measured between 16:00 and 22:00 (Fig. 3).

\section{Rainfall events}

Stocking and Elwell (1976) classify a distinct erosive rainfall event as a storm when total rainfall exceeds $12.5 \mathrm{~mm}$, maximum $5 \mathrm{~min}$ intensity exceeds $25 \mathrm{~mm} \cdot \mathrm{h}^{-1}$ and the event is isolated by

\begin{tabular}{|l|l|c|c|c|c|}
\hline \multicolumn{7}{|c|}{ TABLE 1 } \\
& Daily rainfall characteristics measured at the recording stations in the KZN Drakensberg \\
\hline Station & Recording period & $\begin{array}{c}\text { Total daily } \\
\text { rainfall } \\
\text { (mm) }\end{array}$ & $\begin{array}{c}\text { No. of } \\
\text { rain days }\end{array}$ & $\begin{array}{c}\text { Maximum } \\
\text { daily rainfall } \\
\text { (mm) }\end{array}$ & $\begin{array}{c}\text { Mean rainfall/ } \\
\text { rain day }\end{array}$ \\
\hline Sani Pass (2 850 m a.m.s.l.) & Dec 2001 to Apr 2003 & 1303.6 & 210 & 55.6 & 6.2 \\
\hline Outpost (1 920 m a.m.s.l.) & Dec 2001 to Apr 2003 & 1345.6 & 205 & 44.4 & 6.7 \\
\hline RNNP (1 392 m a.m.s.l.) & Dec 2001 to Apr 2003 & 1559.4 & 166 & 59.8 & 9.4 \\
\hline Glenisla (1 060 m a.m.s.l.) & Dec 2001 to Apr 2003 & 1139.0 & 139 & 62.4 & 8.2 \\
\hline Sentinel Peak (3 165 m a.m.s.l.) & 2003 & 754.4 & 115 & 50.0 & 6.6 \\
\hline Outpost (1 920 m a.m.s.l.) & 2003 & 724.2 & 123 & 44.0 & 5.9 \\
\hline RNNP (1 392 m a.m.s.1.) & 2003 & 773.0 & 96 & 59.8 & 8.1 \\
\hline
\end{tabular}


Figure 3

Timing of daily rainfall

measured at the

respective stations

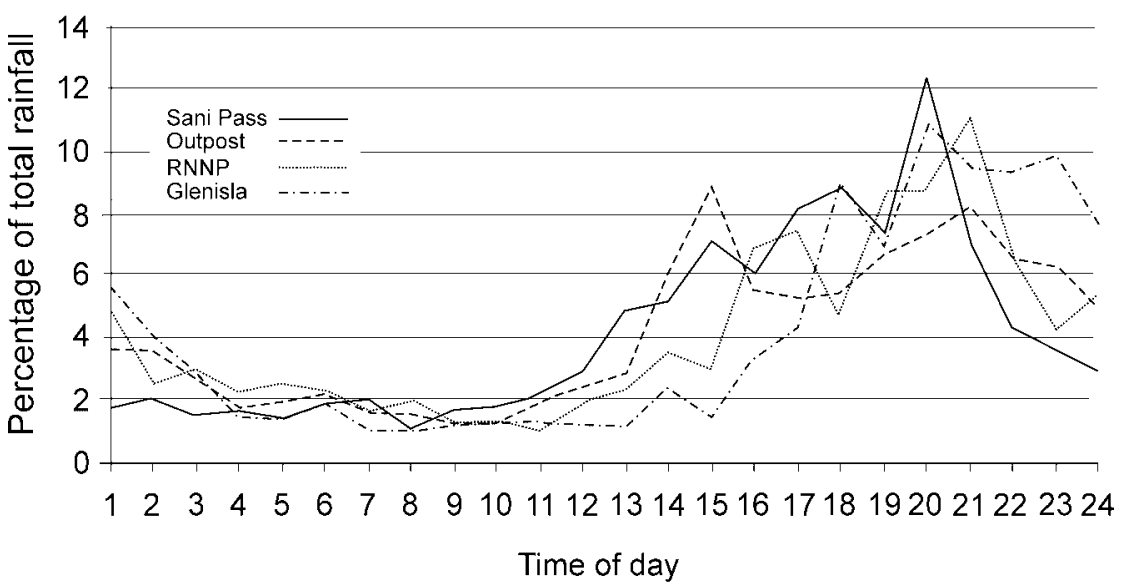

Discussion

at least a rain-free $2 \mathrm{~h}$ period. This definition was also used to assess the intensity and erosivity attributes of rainstorms in the Drakensberg (Nel and Sumner, 2007) as well as the intra-storm attributes of extreme storm events (Nel, 2007). However, for this study the definition by Stocking and Elwell (1976) has been modified to include all rainfall events (erosive and non-erosive). Therefore, a discreet rainfall event is defined as one that generates more than $0.5 \mathrm{~mm}$ of rain and is separated from the next event by more than $3 \mathrm{~h}$. This definition is purely a functional one to delineate individual rain events in the Drakensberg.

Sani Pass measured 231 rainfall events during the recording period, while Injisuthi Outpost, RNNP and Glenisla measured 223, 205 and 161 respectively (Table 2). Rainfall measured from each individual event recorded at the different stations indicates that RNNP has on average the highest amount generated by each event with $7.6 \mathrm{~mm}$ per event. The high-altitude station at Sani Pass has the lowest mean event rainfall with $5.5 \mathrm{~mm}$ per event. All stations show that a high percentage of rain days only record a single rainfall event. Out of the 210 rain days that were recorded at Sani Pass, $162 \mathrm{~d}$ measured only single rainfall events. Injisuthi Outpost, RNNP and Glenisla recorded single events on 156, 127 and $117 \mathrm{~d}$ respectively (Table 2). Of the total rainfall recorded at Glenisla, $81 \%$ is generated during days that only record a single discreet rainfall event (Table 2). Sani Pass has the lowest percentage of total rainfall generated during days with single rainfall events with $61 \%$. Sani Pass and RNNP also have the highest number of days (5) measuring three rainfall events, while the Outpost only measured three discreet rainfall events on $3 \mathrm{~d}$ and Glenisla did not record a single day with three rainfall events. No station recorded more than three discreet rainfall events per day.

The number of rainfall events that generate more than $10 \mathrm{~mm}$ was also considered at each station (Table 2). Rainfall events above this threshold measured at Royal Natal National Park generate approximately $70 \%$ of the total rainfall measured at that station. Rainfall events at Sani Pass with rainfall above 10 mm only generate $47 \%$ of the total rainfall.
Rainfall measured in 2002 at 8 stations in the Drakensberg, all with well-established weather stations, ranges from 78 to $100 \%$ of the mean annual rainfall (MAR) (33 years) and analysis of rainfall in 2003 at 4 stations ranges from 60 to $82 \%$ of the MAR (33 years) ( $\mathrm{Nel}$ and Sumner, 2005). The totals measured from December 2001 to April 2003, and for the year 2003, at the respective stations in this study are thus probably slightly below long-term rainfall averages for the sites. Even though there are latitudinal differences in station positions, latitude is found to play no significant role in influencing rainfall totals ( Nel and Sumner, 2006). Below $2100 \mathrm{~m}$ a.m.s.l. in the Drakensberg, mean annual rainfall is strongly related to altitude and eastward distance from the escarpment ( $\mathrm{Nel}$ and Sumner, 2006). Above $2100 \mathrm{~m}$ a.m.s.l. where no long-term data are available, the trend of increasing precipitation has been assumed to extend to the escarpment summit, where rainfall is anticipated to exceed 1500 mm p/a (Tyson et al., 1976; Schulze, 1979). During the recording period in this study, the two escarpment sites, Sani Pass and Sentinel Peak, recorded less total and mean daily precipitation than the lower altitude stations and the precipitation values at the escarpment edge; therefore, the assumption of increasing rainfall with altitude in the Drakensberg up to the escarpment is challenged. However, even though daily rainfall is less on the escarpment, the number of rain days recorded increases with altitude. Rainfall in the Drakensberg is highly seasonal (Nel and Sumner, 2006) and the monthly distribution of rain days indicates the predominance of rain during the summer months. Erosive storm events across the KwaZulu-Natal Drakensberg vary considerably in duration and the distribution of events is skewed with a bias towards shorter storms ( Nel and Sumner, 2007). However, erosive rainfall events at high-altitude stations tend to be of a longer duration than in stations in the foothills (Nel and Sumner, 2007).

Most rainfall are recorded in the high Drakensberg in the late afternoon/early evening with most stations showing peak

TABLE 2

Rainfall event characteristics measured at the recording stations for the period December 2001 to April 2003

\begin{tabular}{|l|c|c|c|c|c|c|c|c|}
\hline Station & $\begin{array}{c}\text { No of } \\
\text { rainfall } \\
\text { events }\end{array}$ & $\begin{array}{c}\text { Mean event } \\
\text { rainfall } \\
\text { (mm) }\end{array}$ & $\begin{array}{c}\text { Days with } \\
\mathbf{1} \text { event }\end{array}$ & $\begin{array}{c}\text { Rainfall from } \\
\mathbf{1} \text { event/day } \\
\text { (mm) }\end{array}$ & $\begin{array}{c}\text { Percent- } \\
\text { age of total } \\
\text { rainfall }\end{array}$ & $\begin{array}{c}\text { No events } \\
\mathbf{>} \mathbf{1 0} \mathbf{~ m m}\end{array}$ & $\begin{array}{c}\text { Rainfall from } \\
\text { events }>\mathbf{1 0} \\
\text { mm }\end{array}$ & $\begin{array}{c}\text { Percent- } \\
\text { age of total } \\
\text { rainfall }\end{array}$ \\
\hline Sani Pass & 231 & 5.5 & 162 & 795.4 & 61 & 29 & 594.8 & 47 \\
\hline Outpost & 223 & 5.9 & 156 & 835.2 & 62 & 34 & 705.6 & 54 \\
\hline RNNP & 205 & 7.6 & 127 & 1172.4 & 75 & 50 & 1082.2 & 69 \\
\hline Glenisla & 161 & 7.1 & 117 & 922.6 & 81 & 36 & 741.8 & 65 \\
\hline
\end{tabular}


rainfall occurring between 17:00 and 21:00 when sufficient cooling has occurred for condensation and cloud formation. This correlates well with findings from Schulze (1965) who indicates that thunderstorms in the Drakensberg occur in mid- to late afternoon. Thunderstorms in the Drakensberg could be associated with mesoscale convective complexes (MCC) (Laing and Fritsch, 1993) or large-scale line and orographically induced storms (Tyson et al., 1976). Line storms occur in association with the eastward passage of a trough both in the upper air and at the surface (Tyson et al., 1976). Orographically induced storms are probably the most frequent of all storms in the Drakensberg and occur predominantly in summer and are described by Tyson et al., 1976. By midday the lower atmosphere receives moisture from winds blowing to the mountain from the plain and subsidence in the upper westerly winds causes a temperature discontinuity between the lower and upper wind systems. As the plainmountain wind ascends up the escarpment, slope convection along the escarpment increasingly releases convective instability with cloud development taking place.

An increase in the number of rain events with altitude also exists, but less rain falls per event on the escarpment than at the stations at lower altitude. All stations show a high percentage of rain days that record single rainfall events only and these events contribute between 61 and $81 \%$ of the total daily rainfall with a decrease in contribution with altitude. The high-altitude stations also show higher contributions to the overall rainfall totals from rain days that record two or three events. The number of rainfall events that generate more than $10 \mathrm{~mm}$ show that altitudinal difference can also be discerned with regards to the amount of rainfall generated by these high rainfall events. Rainfall events that generated precipitation above this threshold are less on the escarpment than stations in the foothills and Sani Pass only received $47 \%$ of the total rainfall from these events. Therefore, an increase in altitude does not equate to an increase in rainfall intensity. This is comparable to Konrad (1996) who found that in the Blue Ridge Mountains in the south-eastern USA, heavy rain frequency cannot be attributed to elevation alone. At Sentinel Peak rainfall events above $10 \mathrm{~mm}$ generated $60 \%$ of the total rainfall measured during 2003. This compares well to the figure of Berding (1981) for northern Lesotho, where $50 \%$ of the annual rainfall was received by events of $10 \mathrm{~mm}$ or more.

\section{Summary}

The rainfall records presented here are the first data that analyse specific rainfall events in KwaZulu-Natal Drakensberg. The rainfall records challenge the assumption of an increase in rainfall with altitude in the Drakensberg up to the escarpment. Even though daily rainfall and mean rainfall from individual events are less on the escarpment, the number of rain days as well as the number of rainfall events increases with altitude. All stations also show a high percentage of rain days recording single rainfall events and these events contribute between 61 and $81 \%$ of the total daily rainfall. However, the station on the escarpment has a lower contribution to the overall rainfall totals from rain days with single rainfall events than the low-altitude stations.

Clear altitudinal differences also exist with regards to the amount of rainfall generated by events of $10 \mathrm{~mm}$ or more, with the escarpment stations receiving less rainfall from high rainfall events than the stations in the foothills. Most rainfall events in the high Drakensberg occur in the late afternoon/early evening when sufficient cooling would have occurred to cause condensation and cloud formation.

\section{Acknowledgements}

The Department of Geography, Geoinformatics and Meteorology at the University of Pretoria supplied the Davis-MC Systems (D-MCS) equipment. The Govan Mbeki Research and Development Centre at the University of Fort Hare supplied additional funding. The support of Paul Sumner (University of Pretoria) is appreciated.

\section{References}

BERDING FR (1981) An overview of agroclimatological aspects of Lesotho based on available information. ILUP Min of Agriculture, Cooperative and Marketing, Maseru, Lesotho.

BOELHOUWERS J (1991) Present-day periglacial activity in the Natal Drakensberg: a short review. Permafrost Periglac. Proc. 2 5-12.

GRAB S (2002) Turf exfoliation in the high Drakensberg, Southern Africa. Geogr. Ann. 84A (1) 39-50.

KONRAD C (1996) Relationships between precipitation event types and topography in the southern Blue Ridge mountains of the southeastern USA. Int. J. Climatol. 16 49-62.

LAING AG and FRITSCH JM (1993) Mesoscale convective complexes in Africa. Month. Weath. Rev. 121 2254-2263.

NEL W (2007) Intra-storm attributes of extreme storm events in the Drakensberg, South Africa. Phys. Geogr. 28 158-169.

NEL W and SUMNER PD (2005) First rainfall data from the KZN Drakensberg escarpment edge (2002 and 2003). Water SA 31 (3) 399-402.

NEL W and SUMNER PD (2006) Trends in rainfall total and variability (1970-2000) along the KwaZulu-Natal Drakensberg foothills. S. Afr. Geogr. J. 31 (3) 399-402.

NEL W and SUMNER PD (2007) Intensity, energy and erosivity attributes of rainstorms in the KwaZulu-Natal Drakensberg, South Africa. S. Afr. J. Sci. 103 398-402.

NEL W and SUMNER PD (2008) Rainfall and temperature attributes on the Lesotho-Drakensberg escarpment edge, southern Africa. Geogr. Ann. 90A (1) 97-108.

SCHULZE BR (1965) Hail and thunderstorm frequency in South Africa. Notos. 14 67-71.

SCHULZE RE (1979) Hydrology and Water Resources of the Drakensberg. Natal Town and Regional Planning Commission, Pietermaritzburg. 179 pp.

STOCKING MA and ELWELL HA (1976) Rainfall erosivity over Rhodesia. Inst. Br. Geog. Trans. 1 231-245.

TYSON PD, PRESTON-WHYTE RA and SCHULZE RE (1976) The Climate of the Drakensberg. Natal Town and Regional Planning Commission, Pietermaritzburg. $82 \mathrm{pp}$.

WHITMORE JS (1970) The hydrology of Natal. Paper No. 1, $2^{\text {nd }}$ Technical Session, Proc. Symposium Water Natal. Durban, South Africa. 